\title{
Development of Biofuels in China: Progress, Government Policies and Future Prospects
}

\author{
ZHANG HONGZHOU
}

\begin{abstract}
China is the largest energy consumer in the world, but has limited energy resources. Energy security is thus a primary concern for China. Over reliance on the consumption of fossil energy has resulted in severe environmental pollution, which puts pressure on the government to adjust its energy mix. To strengthen its energy supply and prevent further environmental degradation, China has been committed to developing renewable energies, such as biofuels. This article provides a comprehensive assessment of the development of biofuels, rural household biogas, and bioethanol, in particular. It also examines related government policies and the future prospects of the biofuel sector. The analysis shows that remarkable achievements have been made in the development of biogas in rural areas and in bioethanol at the industrial level. This progress is largely credited to government's strong support for the biofuel sectors. Nonetheless, although ongoing energy insecurity and environmental pollution continues to motivate the central government to support the development of biofuels, widening domestic food supply and demand gap, changes in rural life and agricultural industrialization constrain the further expansion of rural household biogas and cereal-based bioethanol. This article suggests that while China urgently needs to find alternative feedstock for the existing rural household biogas digesters and bioethanol plants, centralized biogas and noncereal-based bioethanol projects should be prioritized for future development.
\end{abstract}

Keywords: Biofuels, Energy Security, Food Security, Environmental Pollution, Three Rural Issues

\section{Introduction}

China's phenomenal economic development over the past three decades has been fuelled by intensive utilization of fossil energy resources such as coal, oil and gas. In 2012, China consumed 3.62 billion tons of standard coal equivalents, making it the largest energy user in the world. Although coal has been the major source of energy to fuel China's growth 
at roughly 70 percent of national energy consumption between 1978 and 2012, oil and gas accounted for nearly 24 percent of energy consumption during the same period (China Bureau of Statistics 2013: 81). While China's coal demand can be largely met by domestic coal production, the domestic production of oil and gas falls well short of rising demand. In 2012, China's oil and gas self-sufficiency rates were only 44 percent and 76.5 percent, respectively. In that year, China imported 271.02 million metric tons of crude oil, or about 5.43 million barrels per day, ${ }^{1}$ and natural gas imports amounted to 42.8 billion cubic metres. ${ }^{2}$ News from the US energy Information Administration on 24 March 2014 suggested that China had already overtaken the United States as the world's largest net importer of petroleum and liquid fuels. ${ }^{3}$

Overreliance on the consumption of fossil fuels has resulted in severe environmental pollution. Air pollution in China has reached intolerable levels and thus become a huge public concern; it poses a direct threat to the country's economic development and social stability. Confronted with the double challenge of increasing energy shortages and environmental pollution, China has made huge efforts to promote the development of alternative and cleaner energies, such as solar, hydropower, wind power and biofuels.

A domestic biofuel industry is considered an attractive option for China and the country has invested billions of dollars to promote the development of biofuels. Biofuels include liquid and gaseous fuels that are derived from biomass (organic materials). In China, the two main types of biofuel produced are biogas and bioethanol. ${ }^{4}$ China is now the world's leading producer of biogas. By the end of 2012, biogas was used in nearly 42.4 million households, including 40.8 million rural households with domestic biogas digesters (Ministry of Agriculture 2013: 450-461). Biogas households accounted for nearly a quarter of all the rural households in China. In the same year, China produced 15.7 billion cubic meters of biogas, equivalent to replacing over 24 million tons of standard coal, or 12.6 percent of the country's total natural gas consumption. In terms of bioethanol, China's annual production in 2012 was 1.66 million tons, making it the third largest national producer after the United States and Brazil (Renewable Energy Policy Network for the 21st Century 2013: 7-31).

While the development in both biogas and bioethanol sectors has been quite impressive over the past decade, both are facing significant challenges. Domestic biogas development in China is now at a crossroads, and government investment is likely to decline. With the rapid rise of the commercial animal husbandry sector, fewer animals are kept as livestock 
in rural households, which results in less animal manure ${ }^{5}$ to feed into the biogas digesters. Massive outflow of the rural labour force, particularly of the young and educated rural population, results in less human waste, kitchen residue and available labour to operate and maintain the biogas plant. These combined factors have led to a large number of biogas digesters either functioning below their full potential or falling entirely out of use. Similarly, the development of bioethanol is constrained by the country's overwhelming concern about food security. After supplies of stale grain quickly ran out, most of China's bioethanol plants had to rely on fresh grains, mostly maize. Yet, with the outbreak of the global food crisis in 2007/2008, the Chinese government issued strict policies to halt the development of the deep maize processing industry ${ }^{6}$ including cerealbased biofuel production. The targets for annual bioethanol production were scaled down. With growing pressure on China to produce enough food to feed its population of nearly 1.4 billion, food security will remain a primary concern for the government. This focus does not bode well for the future prospects of the development of bioethanol in China.

This article aims to provide an up-to-date assessment of the development of biogas and bioethanol in China, review the government's supporting policies, examine the emerging opportunities and challenges facing these two sectors, and consider how these challenges can be addressed in the future. Towards this end, the rest of the article is organized as follows: Section 2 outlines the current status of the development of biogas and bioethanol in China. Section 3 discusses government policies, which are vital to the development of biofuels in China. Section 4 presents the future prospects of biofuels in China through an examination of the implications of several key trends in the sector. The last section concludes the paper with some suggestions on the future development of biofuels in China.

\section{Development of Biofuels in China}

Driven by growing concerns over energy security, environmental pollution, and rural population issues, China has made substantial efforts to develop its biofuels sectors: primarily biogas in rural areas and bioethanol at the industrial level.

\section{Development and Current Status of Biogas}

China has been pioneering biogas production since the 1930s, when a few companies tried to commercialize biogas as an alternative fuel for lighting (Xia Zhuzhang 2013). With the establishment of the People's 
Republic, China launched its first official campaign to promote biogas technology in the late 1950s, though this project failed for various reasons, including a lack of construction materials such as cement. In the 1970s, a massive campaign of biogas construction was launched. From 1970 to 1980, the total number of domestic biogas digesters jumped from 6000 to over 7 million. However, these biogas digesters were not of the best quality and had a short functional lifespan. As result, large numbers of biogas digesters constructed during this period dropped quickly out of service. This was followed by a slow but steady development period from the mid-1980s to the late 1990s.

In 2000, following the establishment of the Ministry of Agriculture's 'Rural Ecological Enrichment Project', biogas construction projects were implemented all over the country. Later, in 2003, the central government decided to provide financial support to farmers to boost biogas. From 2003 onwards, rural biogas entered a period of rapid expansion. However, as shown in Figure 1, the growth rate of new biogas digesters in rural areas has slowed since 2009.

Despite this recent slow-down, the development and spread of biogas is remarkable. By the end of 2012, the country's total biogas users totalled nearly 42.4 million households, providing biogas for over 150 million rural residents. Among the biogas users, there were 40.8 million rural households with domestic biogas digesters (Ministry of Agriculture 2013: 450). Biogas households accounted for nearly a quarter of the rural households in China, and were used in up to NOT of 40 percent

FIGURE 1. Development of Household Biogas in China

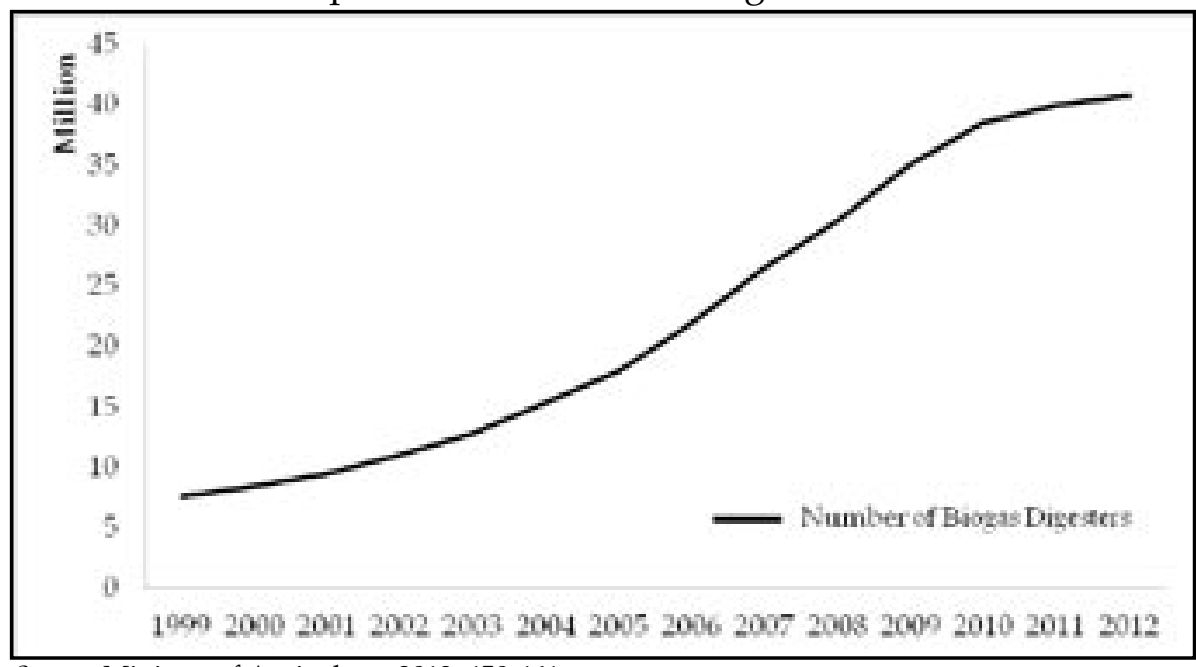

Source: Ministry of Agriculture 2013: 450-461. 
of households which are suitable for biogas digester technology. ${ }^{7}$ In the same year, China produced 15.7 billion $\mathrm{m}^{3}$ of biogas, equivalent to replacing over 24 million tons of standard coal, or 12.6 percent of the country's total natural gas consumption (Ministry of Agriculture 2013: 164).

Apart from rural household biogas digesters, the development of small- to large-scale centralized biogas plants has also grown over the past decades. By the end of 2012, there were 91,952 biogas plants with annual gas production of nearly 2 billion $\mathrm{m}^{3}$, supplying biogas to over 1.5 million households. Among these biogas plants, nearly three quarters were small sized gas plants with daily production ranging between 5 and $150 \mathrm{~m}^{3}$ ( Ministry of Agriculture 2013: 398-404).

To provide support to the progress of rural biogas, the biogas service sector has been developed across the nation. By the end of 2012, there were over 90,000 service stations nationwide, and 800 at the county level, serving over 30 million biogas users. By 2011, there were 12,000 service companies, employing 500,000 people, with annual value added of 26 billion yuan. Strong investment from both the central and local governments, as well as financial assistance from international organisations such as the Asian Development Bank, have played a critical role in the dissemination of biogas technology in China's rural areas, and a variety of biogas digester models have been developed in different regions of the country.

The development of biogas has brought major benefits to China. It allows rural households to convert animal manure, agricultural residue, as well as human and other organic waste into clean cooking fuel and organic fertiliser, providing an effective and non-polluting alternative to fossil fuels, firewood and chemical fertilisers. According to official statistics, China's Biogas digesters and plants processes waste and manure up to 1 billion tons annually, reducing fertilizer and pesticide usage by more than 20 percent, and providing additional income of 48 billion yuan to farmers. According to government estimates, it also reduces carbon dioxide emissions by 50 million tons and produces 400 million tons of organic fertilizers annually (Ministry of Agriculture 2013: 161).

\section{Development and Current Status of Bioethanol}

China's pilot programme for bioethanol started in 2001 and production began in 2002. As seen in Table 1, China's annual production of bioethanol expanded rapidly from 30,000 tons in 2002 to nearly 1.9 million in 2010, when production levels peaked. However, after this peak, production of bioethanol dipped slightly to 1.66 million tons in 2012. 
TABLE 1. Production of Bioethanol in China (thousand tons)

\begin{tabular}{|c|c|c|}
\hline Year & Production & Corn Consumption \\
\hline 2002 & 30 & 100 \\
\hline 2003 & 70 & 200 \\
\hline 2004 & 680 & 690 \\
\hline 2005 & 1020 & 771 \\
\hline 2006 & 1320 & 1933 \\
\hline 2007 & 1450 & 3100 \\
\hline 2008 & 1460 & 3403 \\
\hline 2009 & 1700 & 4620 \\
\hline 2010 & 1870 & 4937 \\
\hline 2011 & 1770 & 4673 \\
\hline 2012 & 1660 & 4382 \\
\hline
\end{tabular}

Source: Cheng Xiaodun et al. 2013. ${ }^{8}$

At the time of writing, China has five ethanol plants: four plants use grain (corn and wheat) and one uses tubers (cassava). For these cerealbased bioethanol plants, corn accounts for 82 percent of feedstock, and wheat 18 percent (Scott and Junyang 2012). All four bioethanol plants which were authorized by the government to produce fuel ethanol from grains are located in the major grain producing provinces: Jilin Fuel Ethanol Co. Ltd and Heilongjiang Huarun Ethanol Co. Ltd in the Northeast region, Anhui Fengyuan Biochemical Co. Ltd in the south, and Henan Tianguan Group in the central region. In 2007, the government set up bioethanol plants using cassava as the main feedstock in Guangxi province. The bioethanol produced from these plants are consumed locally and in nearby cities. For instance, Jilin Fuel Ethanol Co. Ltd has an annual production capacity of 300,000 tons: 100,000 tons of the bioethanol produced by Jilin Fuel Ethanol Co. Ltd would be consumed in the province and the other 200,000 tons would be distributed in Liaoning. Of the 300,000 tons of fuel ethanol produced by Henan Tianguan Group, 130,000 tons would be consumed locally and the rest would be distributed to 13 cities in Hubei and Hebei (Dong Fengxia 2007).

While the development of cereal-based bioethanol production is being halted due to food security concerns, China's long term policy is to continue to promote the development of non-cereal-based bioethanol production. Apart from the already operational cassava ethanol plant which is located in Guangxi province,it was reported that the government 
approved the construction of two plants in Zhejiang and Guangdong in 2012. However, these two plants mainly rely on imported cassava for their initial feedstock supplies due to limited domestic production (Scott and Junyang 2013: 2). Sweet sorghum is another non-grain feedstock that can be used for bioethanol production. China's first commercial bioethanol plants relying on sweet sorghum as feedstock are currently being constructed in Inner Mongolia. The production capacity of these plants is expected to reach 100,000 tons by 2015 (Ibid.: 4).

\section{Government Policies}

The development of biogas and bioethanol is largely driven by government policies which are determined by the three key factors, as shown in Figure 2.

FIGURE 2. Key Factors Influencing China's Policies on Biofuel Development

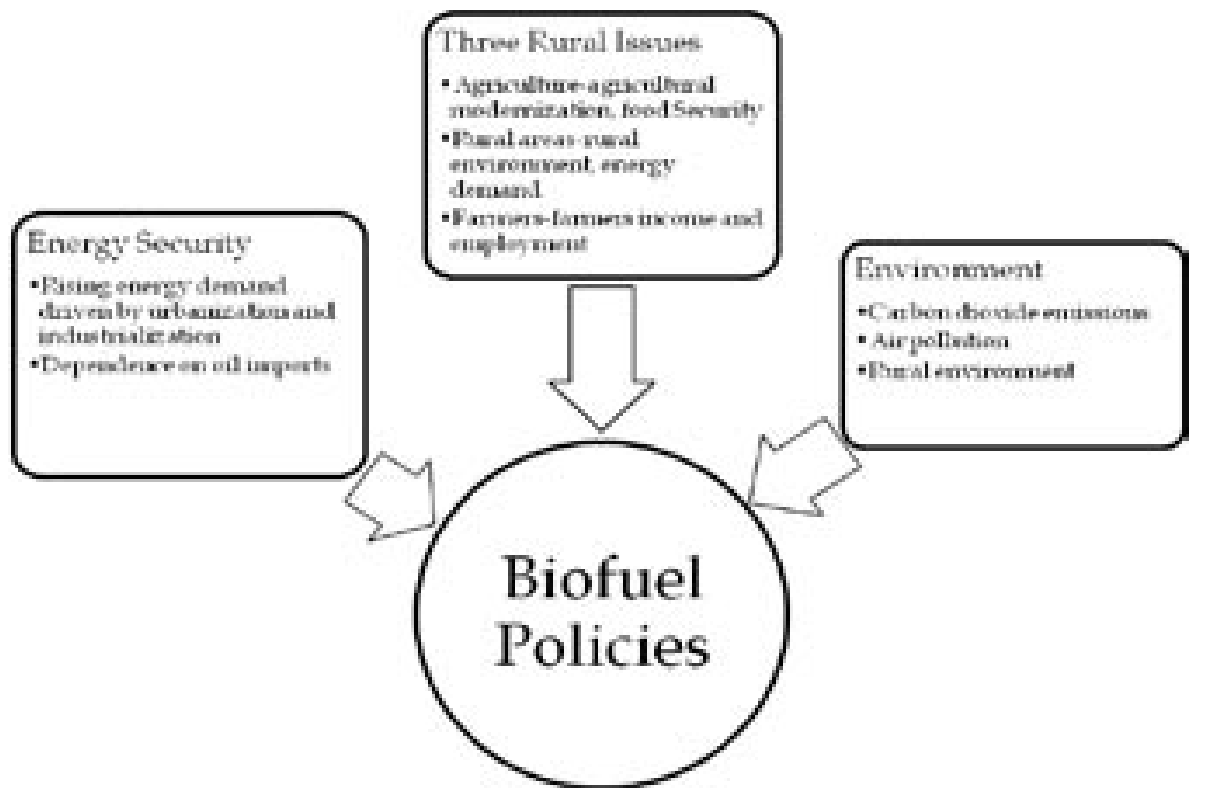

The first factor is energy security. Mounting concern over energy security has been the major impetus for China's investment in biofuels. China considers the development of biofuels as a potential solution to the country's energy shortage. Growing air pollution and greenhouse gas emissions attributed to China's overreliance on fossil energy resources further motivates China to develop cleaner energies, 
including biofuels. In contrast to the development of other renewable energies - such as wind, solar and hydro power - there are other major considerations underpinning the development of biofuels, most notably rural issues concerning agriculture, the rural environment and energy demand, and farmers' livelihoods. On the one hand, China views the development of biogas and biofuel as a way to support farm incomes, facilitate adjustments to agricultural production structures and to protect the rural environment. On the other hand, availability of feedstock (animal manure, agricultural residue and other organic waste for biogas production, and cereals and other feed crops for bioethanol production) and operational feasibility (particularly in the case of rural biogas digesters)are also major considerations informing the country's biofuel policies.

\section{Government Policies Related to the Development of Biogas}

Strong central government support is the key to the rapid expansion of the biogas sector. As presented in Table 2, prior to 2003, while China had launched several rounds of national campaigns to develop biogas in rural areas, these efforts achieved very limited success due to lack of financial support from government and technical drawbacks. In the early 2000s, in recognition of biogas' potential for improving rural living conditions and farmers' livelihoods, and facilitating agricultural structural adjustment, the central government made the development of biogas in rural areas one of the key national projects. In 2003, a 1 billion yuan state bond was issued to support the development of biogas across the country. The projects covered 540 counties across 24 provinces, benefiting over 1 million rural households. Since then, with strong central government support, the biogas sector has entered a new phase of rapid and sustainable development. To increase energy supply, adjust the country's energy mix and protect the environment, China's National People's Congress passed the 'Renewable Energy Law' in February 2005 (it came into force in 2006). The law required central and local governments to provide financial support for the development of biogas in rural areas. In addition, the law allowed biomass power projects, including biogas, access to the grid so that electricity can be sold by the generating company to the grid with a feed-in tariff. This increased the importance of biogas utilization for electricity generation, increasing interest in biogas power projects. 
TABLE 2. Major Government Support for China's Biogas Sector

\begin{tabular}{|c|c|c|}
\hline & Policy documents & Main points of the policies \\
\hline $\begin{array}{l}\text { From 1950s } \\
\text { to late- } \\
\text { 1990s }\end{array}$ & $\begin{array}{l}\text { Several major campaigns initiated } \\
\text { by Chinese government }\end{array}$ & $\begin{array}{l}\text { Due to various constrains, these } \\
\text { efforts only achieved only limited } \\
\text { success }\end{array}$ \\
\hline 2000 & $\begin{array}{l}\text { Ministry of Agriculture introduced } \\
\text { the 'Biological Enrichment of the } \\
\text { Countryside Project' }\end{array}$ & $\begin{array}{l}\text { Development of biogas identified as } \\
\text { key component of the project }\end{array}$ \\
\hline 2003 & $\begin{array}{l}\text { China issued the 'Rural Household } \\
\text { Biogas State Bond' }\end{array}$ & $\begin{array}{l}\text { Significant increase in government } \\
\text { investment in the development of } \\
\text { rural biogas }\end{array}$ \\
\hline 2004 & $\begin{array}{l}\text { The 'Biological Enrichment of } \\
\text { the Countryside Project', which } \\
\text { centred on rural biogas was listed } \\
\text { as one of the major duties of the } \\
\text { Ministry of Agriculture }\end{array}$ & $\begin{array}{l}\text { Plan to build biogas digesters for } \\
\text { 1million rural households covering } \\
5000 \text { villages nationwide }\end{array}$ \\
\hline 2005 & 'Renewable Energy Law' issued & $\begin{array}{l}\text { Promote the development and } \\
\text { utilization of renewable energies, } \\
\text { including biogas }\end{array}$ \\
\hline 2006 & $\begin{array}{l}\text { Ministry of Agriculture issued the } \\
2006 \text { 'Rural Energy Comprehen- } \\
\text { sives Construction Project Fund } \\
\text { Notice' }\end{array}$ & $\begin{array}{l}\text { Provide further financial support to } \\
\text { the development of biogas in rural } \\
\text { areas }\end{array}$ \\
\hline 2007 & $\begin{array}{l}\text { Ministry of Agriculture issued } \\
\text { 'National Rural Biogas Projects } \\
\text { Development Plan 2006-2010' }\end{array}$ & $\begin{array}{l}\text { By } 2010, \text { rural household users } \\
\text { reach } 40 \text { million, and medium- } \\
\text { and large-scale biogas plants will } \\
\text { reach } 4700\end{array}$ \\
\hline 2007 & $\begin{array}{l}\text { 'National Plan of Building Rural } \\
\text { Biogas Service System' issued in } \\
2007\end{array}$ & $\begin{array}{l}\text { Provide financial support to } \\
\text { development biogas service system }\end{array}$ \\
\hline 2007 & $\begin{array}{l}\text { 'Development Plan of China's Agri- } \\
\text { cultural Bioenergy Industry' issued }\end{array}$ & $\begin{array}{l}\text { Development of biogas is priori- } \\
\text { tized }\end{array}$ \\
\hline $2008-2012$ & $\begin{array}{l}\text { Number } 1 \text { Document of the State } \\
\text { Council }\end{array}$ & $\begin{array}{l}\text { For five consecutive years, Number } \\
1 \text { document put out specific } \\
\text { requirements for the development } \\
\text { of rural energy, biogas in particular }\end{array}$ \\
\hline 2009 & \begin{tabular}{|l} 
'National Rural Biogas Service \\
System Construction Plan' (Trial)
\end{tabular} & $\begin{array}{l}\text { Provide financial support to build } \\
\text { up rural biogas service system }\end{array}$ \\
\hline 2010 & $\begin{array}{l}\text { 'Renewable Energy Development } \\
\text { 12th Five Year Plan' }\end{array}$ & $\begin{array}{l}\text { Rural biogas users to reach } 50 \\
\text { million in } 2015\end{array}$ \\
\hline 2011 & $\begin{array}{l}\text { State Council issued the } 12 \text { th Five } \\
\text { Year plan energy conservancy and } \\
\text { on emission reduction }\end{array}$ & $\begin{array}{l}\text { Develop rural biogas and medium } \\
\text { and big biogas plants }\end{array}$ \\
\hline 2012 & $\begin{array}{l}\text { Opinions on further enhancing } \\
\text { the construction of biogas in rural } \\
\text { areas }\end{array}$ & $\begin{array}{l}\text { Scientific planning for the devel- } \\
\text { opment of biogas, widen the raw } \\
\text { materials used, improve quality and } \\
\text { enhance service system }\end{array}$ \\
\hline 2012 & $\begin{array}{l}\text { China Rural Economy } \\
\text { Development 12th Five Year plan }\end{array}$ & $\begin{array}{l}\text { Rural household biogas users will } \\
\text { constitute up to } 50 \% \text { of the total } \\
\text { suitable rural households }\end{array}$ \\
\hline
\end{tabular}

Source: Author's compilation, based on various government documents on policies, regulations and laws. 
In 2006, against a background of rising rural unrest, China unveiled the plan to build a 'new socialist countryside'. The leadership has regarded biogas as a means to provide alternative markets for produce from China's impoverished rural areas. The Eleventh Five-Year Plan (2006-2010) and the policy of 'Building a New Socialist Countryside' aim to modernize rural China while mitigating the negative impact of intensified agriculture on the environment. Renewable energy, biogas in particular, has the potential to support this goal. The Chinese government also promotes biogas systems as part of campaigns and policies like 'Three Rural Issues' (2005), 'Circular Economy Policy' (2005) and 'Ecological Garden Projects' (2000). Furthermore, with growing pressure to ensure environmental protection, biogas projects - particularly the development of medium- to large-sized biogas plants - became an important alternative means for China to deal with animal manure and organic sewage (Wang Fei et al. 2012). In 2007, the Ministry of Agriculture issued the 'National Rural Biogas Projects Development Plan 2006-2010', further boosting support for the development of medium- to large-scale biogas projects. Also, during the global financial crisis in 2008, China included rural biogas in the national package plan which aimed to expand rural consumption and revive the national economy.

Between 2003 and 2012, Chinese central government allocated over 31.5 billion yuan to promoting the development of rural biogas. Spurred on by this strong commitment, local governments invested nearly 14 billion yuan, plus 46.4 billion yuan investment by the farmers. In 2011, to balance the rising costs of building, central government subsidies to biogas businesses increased to 1300, 1600 and 2000 yuan for the Eastern, Central and Western regions, respectively.

However, the sector quickly encountered sustainability problems, mainly because of the rapid pace of change in the agricultural sector, rural livelihood issues and failings in the underdeveloped biogas service system. To address these problems, the government published the 'National Rural Biogas Service System Construction Plan' in 2007, and it began to focus more on the development of medium-size as well as large biogas projects. This emphasis was highlighted in subsequent government policies, such as the '12th Five Year Plan for Energy Conservancy and Emission Reduction' in 2011 and the 'Opinions on further enhancing the construction of biogas in rural areas' issued in 2012, which again emphasised the need to broaden the source of feedstock and develop medium- to large-scale biogas projects. 
Despite the problems encountered, China is still determined to tap the full potential of biogas in rural areas. According to the 'Renewable Energy Development 12th Five Year Plan' and 'China Rural Economy Development 12th Five Year Plan' both published in 2012, the country will continue to expand biogas usage in rural areas. By 2015, the country aims to have increased the number of rural biogas household digesters to 50 million, 50 percent of the total suitable rural households.

\section{Government Policies Related to the Development of Bioethanol}

China initiated its bioethanol programme in 2001, when the country had an excess of stale grains in its national reserve. As with the development of biogas, the Chinese government viewed the biofuels industry as a means of addressing the Three Rural Issues by providing alternative markets for grain and improving incomes and employment opportunities in China's impoverished rural areas. Since then, as shown in Table 3 , series of government policies have been introduced to encourage the development of bioethanol. In 2002, Chinese government announced the 'Pilot Testing Program of Bioethanol Gasoline for Automobiles' in two major grain producing provinces, Henan and Heilongjiang. Shortly afterwards, the test programme was expanded to provide a direct subsidy to bioethanol production. In the meantime, four bioethanol plants using stale maize and wheat were approved and established in Heilongjiang, Jilin, Anhui and Henan provinces.

TABLE 3. Major Government Support for China's Bioethanol Sector

\begin{tabular}{|l|l|l|}
\hline Year & Policy documents & Main points of the policies \\
\hline $\begin{array}{l}\text { Pre- } \\
2000\end{array}$ & $\begin{array}{l}\text { No specific government policy on } \\
\text { bioethanol development }\end{array}$ & $\begin{array}{l}\text { China has supported liquid } \\
\text { biofuel development through } \\
\text { investment in R\&D and biofuel } \\
\text { technologies }\end{array}$ \\
\hline 2001 & $\begin{array}{l}\text { 'Special Development Plan for } \\
\text { Denatured Fuel Ethanol; Bioetha- } \\
\text { nol Gasoline for Automobiles' in } \\
\text { the 10th Five-Year Plan }\end{array}$ & $\begin{array}{l}\text { To experiment with bioethanol } \\
\text { production using stale grain } \\
\text { stocks using supportive measures }\end{array}$ \\
\hline 2002 & $\begin{array}{l}\text { 'Pilot Testing Program of Bioetha- } \\
\text { nol Gasoline for Automobiles' }\end{array}$ & $\begin{array}{l}\text { National standards for denatured } \\
\text { bioethanol and E10 } \text { were formu- } \\
\text { lated; five cities in Henan and } \\
\text { Heilongjiang selected to use E10 }\end{array}$ \\
\hline 2004 & $\begin{array}{l}\text { 'Expanded Pilot Testing Program } \\
\text { of Bioethanol Gasoline for Auto- } \\
\text { mobiles' }\end{array}$ & $\begin{array}{l}\text { Five provinces and 27 cities were } \\
\text { selected to participate in the sec- } \\
\text { ond phase of expanded testing }\end{array}$ \\
\hline
\end{tabular}




\begin{tabular}{|c|c|c|}
\hline 2004 & $\begin{array}{l}\text { 'Guidance of Ministry of Finance } \\
\text { on Covering the Loss of Bioetha- } \\
\text { nol Plants from Bioethanol Pro- } \\
\text { ductions' }\end{array}$ & $\begin{array}{l}\text { To cover the loss of plants from } \\
\text { bioethanol production, a direct } \\
\text { subsidy for bioethanol produc- } \\
\text { tion was set up for 2004-2008 }\end{array}$ \\
\hline 2005 & 'Renewable Energy Law' of China & $\begin{array}{l}\text { Promote the development and } \\
\text { utilization of renewable energies, } \\
\text { including liquid biofuels }\end{array}$ \\
\hline 2005 & $\begin{array}{l}\text { 'Supportive Policies of the Min- } \\
\text { istry of Finance on Bioethanol } \\
\text { Production' }\end{array}$ & $\begin{array}{l}\text { A set of supportive policies for } \\
\text { bioethanol production and exten- } \\
\text { sion was released }\end{array}$ \\
\hline 2006 & $\begin{array}{l}\text { 'Announcement regarding } \\
\text { Strengthening Management of } \\
\text { Bioethanol Projects and Promot- } \\
\text { ing Healthy Development of } \\
\text { Ethanol Industry' }\end{array}$ & $\begin{array}{l}\text { Restrict market access of bioetha- } \\
\text { nol production; encourage the } \\
\text { development of non-cereal-based } \\
\text { bioethanol }\end{array}$ \\
\hline 2006 & $\begin{array}{l}\text { 'Policy Provision on Financial } \\
\text { Support to Biofuel and Biochemi- } \\
\text { cal Industries' }\end{array}$ & $\begin{array}{l}\text { Financial supporting policies on } \\
\text { biofuel production were adjusted }\end{array}$ \\
\hline 2006 & $\begin{array}{l}\text { Guidance on the Implementation } \\
\text { of Financial Support to Non-ce- } \\
\text { real-based Biofuel Development' }\end{array}$ & $\begin{array}{l}\text { Central government subsidizes } \\
\text { the construction of non-cereal- } \\
\text { based biofuel plants through low } \\
\text { interest low and direct subsidy }\end{array}$ \\
\hline 2007 & $\begin{array}{l}\text { 'Medium and Long-term De- } \\
\text { velopment Plan for Renewable } \\
\text { Energy' }\end{array}$ & $\begin{array}{l}\text { Set the targets for biofuel produc- } \\
\text { tion in } 2010 \text { and } 2020\end{array}$ \\
\hline 2007 & $\begin{array}{l}\text { 'Development Plan of China's Ag- } \\
\text { ricultural Bioenergy Industry' }\end{array}$ & $\begin{array}{l}\text { Major feedstocks that may be } \\
\text { used for liquid biofuel develop- } \\
\text { ment listed }\end{array}$ \\
\hline 2007 & $\begin{array}{l}\text { 'Temporary policy Provision on } \\
\text { Financial Subsidies to Production } \\
\text { Bases of Feedstocks for Biofuel } \\
\text { and Biochemical Industry' }\end{array}$ & $\begin{array}{l}\text { Bioenergy trees and non-cereal } \\
\text { feedstocks planted on marginal } \\
\text { lands will be subsidized by } 3000 \\
\text { yuan/ha, and } 2700 \text { yuan/ha, } \\
\text { respectively }\end{array}$ \\
\hline 2007 & $\begin{array}{l}\text { 'Planning for China's Bio-forestry } \\
\text { Development' }\end{array}$ & $\begin{array}{l}\text { A target for energy tree planta- } \\
\text { tion by } 2020 \text { was set }\end{array}$ \\
\hline 2007 & $\begin{array}{l}\text { 'Renewable Energy Development } \\
\text { 11th Five Year Plan' }\end{array}$ & $\begin{array}{l}\text { 'Biofuel must not compete with } \\
\text { grain over land, it must not com- } \\
\text { pete with food that consumers de- } \\
\text { mand, it must not compete with } \\
\text { feed for livestock and it must not } \\
\text { inflict harm on the environment' }\end{array}$ \\
\hline $\begin{array}{l}2007- \\
2010\end{array}$ & $\begin{array}{l}\text { China's Development and Reform } \\
\text { Commission issues guidance } \\
\text { on the maize deep processing } \\
\text { industry }^{10}\end{array}$ & $\begin{array}{l}\text { Halt maize-based biofuel produc- } \\
\text { tion }\end{array}$ \\
\hline
\end{tabular}




\begin{tabular}{|l|l|l|}
\hline 2009 & $\begin{array}{l}\text { 'Several Policy Measures to } \\
\text { Accelerate the Development of } \\
\text { Bioenergy' }\end{array}$ & $\begin{array}{l}\text { Increase financial support and } \\
\text { explore new channels for finances } \\
\text { to develop bioenergy }\end{array}$ \\
\hline 2011 & $\begin{array}{l}\text { 'Development Plan and Cultiva- } \\
\text { tion Guidance on Energy Forest' }\end{array}$ & $\begin{array}{l}\text { Energy crop or forestry growing } \\
\text { should make use of saline land, } \\
\text { and waste land and hill }\end{array}$ \\
\hline 2012 & $\begin{array}{l}\text { 'Bioenergy Technology Develop- } \\
\text { ment 12th Five Year Major Project } \\
\text { Planning' }\end{array}$ & $\begin{array}{l}\text { Continue to provide financial and } \\
\text { policy support, attract private } \\
\text { participation and investment }\end{array}$ \\
\hline 'Renewable Energy Development & $\begin{array}{l}\text { Annual production of bioethanol } \\
\text { to reach 3.4-4 million tons }\end{array}$ \\
\hline
\end{tabular}

Source: Author's compilation based on various government documents on policies, regulations and laws; and Qiu et al. 2009.

As the production costs of bioethanol is still very high, the government provides large subsidies to encourage the development of bioethanol production. In 2009, China's subsidy for cereal-based bioethanol production was USD 241 per ton (Scott and Junyang 2012: 3). In addition, ethanol plants are exempt from the 5 percent consumption tax and are able to get refunds of the value-added tax. ${ }^{11}$ In the early years, the four plants received a stale-grain subsidy for utilizing stale grains in denatured fuel ethanol production. However, due to concerns about food security, China has significantly reduced its subsidies for cereal-based bioethanol production. In 2012, the country's average subsidy for cerealbased production was reduced to USD 79 per ton (Scott and Junyang 2013: 3); in 2015 the government is also stopping the value added tax rebate and imposing a 5 percent consumption tax. ${ }^{12}$ Indeed, in 2007, it was announced that the government would not approve the construction of new cereal-based bioethanol plants. ${ }^{13}$ In the subsequent years, while government policy has continued to the importance of developing biofuels, the focus has been shifted to non-cereal-based production. In the 2012 'Renewable Energy Development 12th Five Year Plan', the government set a modest goal of an annual production of 4 million tons by 2020 .

\section{Future Prospects}

Although the 'Renewable Energy Development 12th Five Year Plan' has set quite ambitious goals for the development of both biogas and bioethanol from 2011 to 2015, the long-term prospects of biofuels, and the feasibility of these goals beyond 2015, remains in question. The data on the development of biogas and bioethanol up until 2012-2015seems 
to suggest a very slow start. Given the high production costs, tight government controls, and marginal role of the market, the pace of commercialization of the biogas and bioethanol sectors in has been quite slow. ${ }^{14}$ Both the historical record and academic field surveys indicate that the government's policies (including policies directly related to or indirectly affecting biofuels) have been the dominant force shaping the development of biofuels. ${ }^{15}$ It is therefore assumed that the future trajectory of the development of biofuels will continue to be predominately influenced by government policies, which in turn will be determined by the three key factors: energy security, environmental pollution and the 'Three Rural Issues'.

\section{Rising Energy Dependency and Environmental Pollution}

Driven by steady economic growth, accelerated urbanization and the dramatic expansion of the transportation sector, China's energy demand, particularly demand for oil and gas, is rising rapidly. Yet, with limited oil and gas resources, China has to increasingly rely on the international market for oil and gas; China is emerging as the world's biggest oil and gas importer. China's net imports of petroleum and other liquid fuels (oil) began to exceed those of the US on a monthly basis in September 2013, making it the largest net importer of crude oil and other liquid fuels in the world. Given that the domestic oil production capability of the US is much bigger and faster growing than that of China, China will remain as the largest oil importer in the future years. ${ }^{16}$

The situation is similar for natural gas. China's natural gas imports are also expected to rise substantially over time and some studies indicate that China will become a major importer of natural gas by 2030 (Pipeline \& Gas Journal 2012). Furthermore, the International Energy Agency reported that global gas demand will expand by an annual average of 2.7 percent, reaching 3.9 trillion cubic metres in 2017, compared with 3.3 trillion cubic metres in 2011. China will be the biggest contributor to that increase as it becomes one of the leading natural gas importers. China's demand for natural gas will grow at an average of 13 percent annually as it becomes the fastest growing market, with consumption doubling from 130 billion cubic metres in 2011 to 273 billion cubic metres in 2017 (Ibid.).

In the meantime, overreliance on fossil energy resources, particularly coal, which represented over 70 percent of the country's energy consumption over the past three decades, has resulted in extreme air pollution. Air pollution has become so bad that it is posing a direct threat to the 
country's economic and social stability. In 2013, the PM2.5 fine particulates in many parts of China reached levels 70 times those considered safe in the West. ${ }^{17}$ Furthermore, as China's emerges as the biggest emitter of greenhouse gas, there are huge international pressures on the country to use less polluting forms of energy. Combining these factors together, China considers development of renewable energy, such as solar, hydropower, wind and biogas, as a key part of its energy development strategy. The 'Renewable Energy Development 12th Five Year Plan' indicates that China aims to increase the share of renewable energy in the country's total energy consumption to be above 11.4 percent by 2015 .

Despite the rapid expansion of biogas and bioethanol over the past decade, the China's biogas potential is far from fully utilized. It is estimated that the quantity of livestock manure (the main feedstock for biogas) produced could reach 4 billion tons by 2020. If the full collectable amount could be used to generate biogas, the energy produced would be equivalent to 160 million tons of standard coal(Yu Cheng et al. 2010). Similarly, over 680 million tons of agricultural residue was produced in 2010, of which around 290 million tons was usable as an energy resource for producing biogas and bioethanol. This is equivalent to over 140 million tons of standard coal. After 2030, it is forecast that 400-500 million tons of agricultural residue can be used to produce bioenergy, equivalent to 200-300 million tons of standard coal .(Yu Cheng et al. 2010). In addition, the potential for producing biofuel using the country's vast forestry resources are yet to be exploited.

Unlike China's policies relating to the other renewable energy sectors, such as solar, wind and hydro power, the policy on biofuels is shaped to address the Three Rural Issues. As discussed in the previous section, the strong support from central government for the development of both biogas and bioethanol has been motivated by the desire to create alternative sources of income for rural residents, improve the rural environment and facilitate agricultural restructuring. For instance, the establishment of the bioethanol industry was initially a response to excess grain reserve stocks which depressed the grain sector and damaged farmers' incomes (Dong Fengxia 2007:4). The primary objective behind the development of rural biogas now seems to have shifted from addressing the rural energy shortage to protecting the rural environment (Xia Zuzhang 2013: 9).

At the practical level, the government's biofuel policy will need to take into consideration the availability of feedstock, including animal and human manure, agricultural residue and other organic waste, and the maintenance and operational feasibility of the biogas digesters: all 
considerations related to the Three Rural Issues. Therefore, looking ahead, while concerns over energy security, environmental pollution (particularly rural environmental degradation) and income disparity continue to inform biofuel policies, the emerging issues of changes to rural life, agricultural industrialization (for biogas) and food insecurity (particularly for bioethanol) pose challenges for the future development of biogas and bioethanol.

\section{Changing Rural Life}

China has undergone rapid urbanization over the past three decades and this has had a huge impact on the development of rural areas. As shown in Figure 3, China's rural population peaked in 1995, when it reached 860 million. Since then, the rural population has begun to decline and it had

FIGURE 3. Chinese Population by Urban/Rural Residence (Number, 10,000)

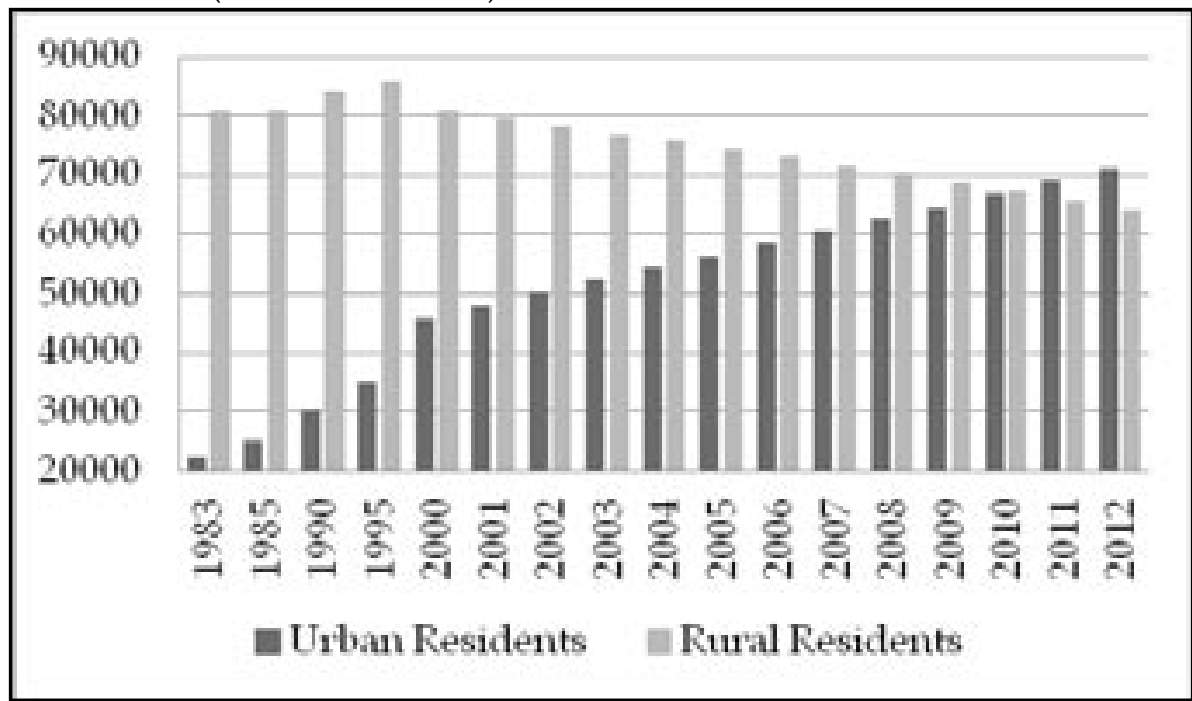

Source: China's Statistical Yearbook 2013.

decreased to 642 million in 2012. The rapid outflow of rural residents has serious implications for the development of rural household biogas. As the construction, operation and maintenance of biogas digesters is labour intensive, the outflow of the rural labour force-mostly young and educated rural workers - inevitably hinders the expansion of biogas in rural areas and results in operational and maintenance difficulties, which in turn contribute to low utilization rates, abandonment of biogas digesters and a low acceptance rate among rural residents towards the biogas technology. In 2013, an official survey revealed that average age of the farmers in Jiangsu Province is 58.6, and that younger people in 
rural areas are shunning agricultural life..$^{18}$ Moreover, human waste and leftover food are important feedstock for biogas production and rapid outflow of rural residents thus also means less available feedstock for biogas production.

Since China's new leadership views urbanization as key to its efforts to launch a new round of reform and considers urbanization to be the main driver of China's economic growth in the future, the pace of urbanization will undoubtedly accelerate in the coming years. ${ }^{19}$ The government forecasts that China's urbanization rate will reach 60 percent in 2020. ${ }^{20}$ This acceleration in changes to rural life will inevitably create further challenges for the development of the biogas sector.

\section{Agricultural Industrialization}

Production of biogas in rural areas is determined by the availability of feedstock, particularly animal manure. Traditionally, large-scale backyard cultivation of livestock, mostly hogs, produced plentiful quantities of animal manure, which was the ideal feedstock for rural biogas digesters. However, the structure of hog farms in China has changed significantly in recent years. Backyard hog farming, which used to dominate the market, has witnessed a sharp decline. At the time of writing, less than 37 percent of hogs come from backyard farms, compared to about 74 percent in 2001, as seen in Figure 4.

The rapid change in China's farming structure began in 2007, when backyard farmers were hit harder than larger-sized farms by outbreaks of disease caused by poor sanitation and inadequate farm management. Backyard farmers are also especially vulnerable to the uncertainty of input costs and market volatility. In addition, with urbanization and migration of rural labour to cities, the opportunity cost of rural labour increased. These factors make backyard farming less competitive when compared to larger-sized farms. As pig manure is the main feedstock for biogas production, the rapid structural change of China's hog industry has huge implications for the development of the biogas sector. On the one hand, rapid commercialization of hog production means that expansion of medium- to large-size biogas plants becomes increasingly feasible and attractive. On the other hand, the decline of backyard hog production leads directly to an increase in the number of rural household biogas digesters being underutilized or even abandoned. According to official statistics, per household biogas annual production has decreased from 397 cubic metres in 2007 to 377 cubic metres in 2012. Between 2007 and 2012, while the number of rural biogas users had increased by 14.6 
million, over 3.3 million biogas digesters had been discarded during the same period (Ministry of Agriculture 2013: 226-451). Academic surveys at the local level suggest that the underutilization and abandonment rate have been much higher than the official numbers given (Xue Xiaofei 2013: 116-117; Zhang Ming and Lai Ming 2007: 2108-2110).

Going forward, it is expected that backyard farming will continue to decline as it becomes less competitive. It is forecasted that by 2015 the share of backyard hog farming in the country's total hog production will shrink to just 27 percent. This means that even less animal manure will be available for biogas production at the rural household level.

FIGURE 4. China's Hog Farming Structure 2001-2015 Forecast

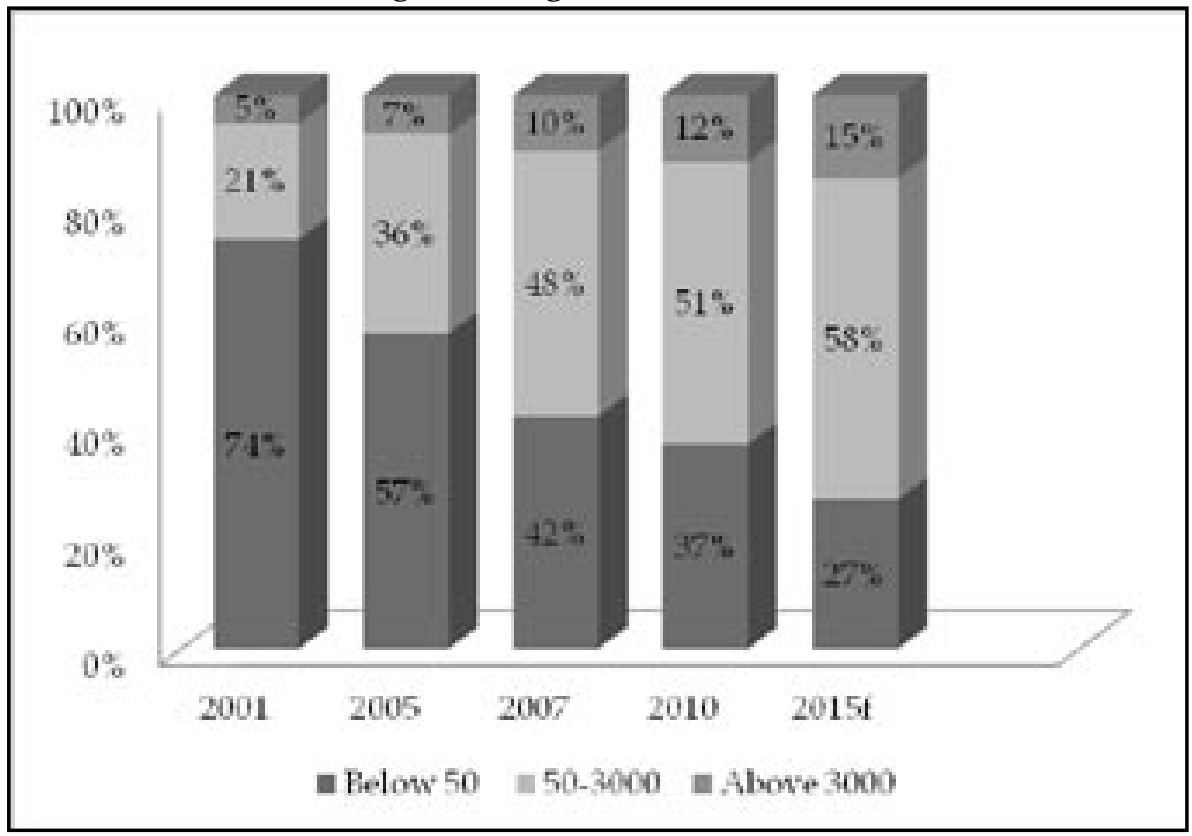

Source: Ministry of Agriculture and Rabobank Estimate 2011.

China's crop production sector is also undergoing major structural change. As discussed in section 4.2, there has been a sustained and massive migration of the young and middle-aged rural labour force to cities in the past decade. As a result, rural areas have seen their farming workforce grow older and less educated. More women are now doing agricultural work. Thus, to eliminate the shortcomings of traditional small-scale farming and urbanization, China has introduced policies to promote the development of family farms ${ }^{21}$ to facilitate specialized, intensive and large-scale agricultural operations. By the end of 2013, the lease titles of 340 million mu (nearly 23 million hectares) of 
land, which represents 26 percent of the country's total arable land, were transferred either to their peers or to agribusiness firms. There were over 2.8 million rural households with a farm size bigger than $50 \mathrm{mu}$ (3.3 hectares) and the total number of family farms reached $870,000.22$

With the decline of backyard hog farming, in many regions agricultural residue has become a major feedstock for biogas production. However, the ongoing trend of land concentration and the development of large-scale family farms results in a growing number of rural households becoming disconnected from grain production. This means that agricultural residue can no longer be taken for granted as feedstock for rural biogas digesters.

\section{Mounting Food Security Concerns}

Maintaining food security has always been a major concern of the Chinese government. For decades, influenced by the painful history of periodic famine and out of the distrust of the international market during the Cold War era, grain self-sufficiency has been the foundation of China's food security. Ensuring sufficient domestic supply of grain has been the overarching objective of China's agricultural sector.

As discussed in section 3.2, the development of bioethanol production has been largely shaped by food security situations. The bioethanol programme started when there was an excess of stale grain in the national reserve. This excess led to huge maintenance costs and grain loss, while simultaneously depressing the national grain market and farmers' enthusiasm for grain production. By 2006, when national grain production could not keep up with domestic demand and the international food security outlook worsened, the Chinese government quickly imposed strict restrictions on the further expansion of cerealbased bioethanol production. In 2007, it issued explicit guidelines on the future development of bioethanol, stating that bioethanol production should neither directly or indirectly undermine the country's food security. Since then, China has concentrated on the development of noncereal-based bioethanol production, using feedstock such as cassava, sweet potatoes and sweet sorghum. However, using this non-cereal feedstock could also undermine the country's food security. Cassava and sweet potatoes, though not staples, are an important element of the Chinese diet, particularly poorer people. Use of sweet sorghum also poses problems because although the government has stressed that it shown be grown on marginal land, the expansion in its production 
will divert water and fertilizers from food crops and thus affect food security (Yang Hailong et al. 2012).

The development of rural biogas is also indirectly affected by the government's food security strategy. Recognizing the limitations of small household grain farming and backyard hog farming, agricultural industrialization is viewed as the key to solving China's food problems. The government has therefore been very supportive of scaling up the sizes of both grain and hog farms, which dramatically changes the structure of feedstock for biogas production.

In the long term, China's food demand and supply gap is set to widen further, driven by population growth, urbanization and economic development. Fan Shenggen, the director general of the International Food Policy Research Institute, forecasts that by 2020 China would need to import 100 million tons of grain each year. ${ }^{23} \mathrm{Xu}$ Xiaoqing, the head of the rural department at the State Council's Development and Research Centre, a government think tank, projected that China could import 20 million-30 million tons of corn per year to cover supply shortages. ${ }^{24}$ According to a joint Agricultural Outlook forecast by the UN agencies OECD and FAO (2013), China's imports of coarse grains, used mostly for fattening herds, are expected to double by 2022. Imports of soybeans will grow 40 percent, while meat imports are set to soar, with beef imports nearly doubling. The widening food gap means that concern over food security will create even bigger challenges for the development of bioethanol and biogas, as the government may toughen measures regulating the deep grain processing sector and accelerate the process of agricultural industrialization.

Given the factors listed above and although energy security and environmental concerns will continue to be a strong driver for the future development of renewable energies, including biofuels, the ongoing trend of changing rural life, agricultural industrialization and domestic food insecurity unmistakably cast serious shadows over the future prospects of biogas and bioethanol. The Chinese government is therefore refocusing its efforts to develop the country's biofuel sectors.

Government investment for developing rural household biogas is likely to decline and the country now focuses more on the development of medium- to large-scale biogas plants while seeking a technological breakthrough in utilizing agricultural residues to generate biogas. Similarly, efforts to develop bioethanol are focusing on non-cereal-based production. However, the future prospects for developing centralized biogas plants and non-cereal-based bioethanol remains unclear, given 
the current technological constraints. Although the potential for relying more on agricultural residue as feedstock is huge, the biological pre-treatment of agricultural residue is still at the experimental stage, presenting difficulties for large-scale application (Yu Chen et al. 2010). Similarly for bioethanol, although non-cereal-based bioethanol production is being prioritized, these crops have relatively low yields and small-scale production, and are still unable to support large-scale industrial ethanol production (Scott and Junyang 2013).

\section{Conclusion}

Driven by concerns over its energy security, environmental pollution and the Three Rural Issues, China has invested substantially in its efforts to development its biofuels sectors, primarily biogas in rural areas and bioethanol at the industrial level. With strong government support, the biogas and bioethanol sectors have made remarkable achievements since the early 2000s, though both face an uncertain future. On the bright side, rising concern over energy security will continue to be the major impetus for China's investment in biofuels as a potential solution to the country's energy shortage and increasing air pollution and greenhouse gas emissions attributed to overreliance on fossil energy resources. However, the dynamics noted in the rubric of the Three Rural Issues pose major challenges to the future development of biogas and bioethanol. Although the development of biogas and biofuel is viewed as a way to support farm incomes, facilitate the structural adjustment of agricultural production and protect the rural environment, growing concerns over food security will directly and indirect restrain the development of biogas and bioethanol in China.

The expansion of rural household biogas and cereal-based bioethanol is not sustainable. Instead, efforts need to be made to find alternative feedstock, such as agricultural residue, for the existing rural household biogas digesters and bioethanol plants. In terms of future development, centralized biogas plants need to be prioritized and bioethanol plants which utilize agricultural residues and forests resources should be promoted. Technological breakthroughs and the commercialization of both biogas and bioethanol sectors hold the key to the future development of biofuels in China. 
Zhang Hongzhou is Associate Research Fellow with the China programme at S. Rajaratnam School of International Studies, Nanyang Technological University, Singapore. He researches China's food, energy and water policies and foreign relations. Email: ishzzhang@ntu.edu.sg

\section{NOTES}

1 Wall Street Journal 2013, 'China Crude-Oil Imports Rose 6.8\% in 2012' available at http:/ / online.wsj.com/article/SB10001424127887324081704578232650955659718. html. Accessed 13 April 2014.

2 People Daily, 'China's reliance on oil-gas imports growing: report' available at http:/ / english.peopledaily.com.cn/90778/8115126.html. Accessed 13 April 2014.

3 EIA news at http://www.eia.gov/todayinenergy/detail.cfm?id=15531. Accessed 13 April 2014.

4 Although China has made efforts to develop biodiesel, these are limited in scale. China only produced around 0.2 billion litres of biodiesel in 2012 .

5 Although commercial livestock farms also produce manure, not much of the manure is being utilized for several reasons. For instance, as commercial livestock farms are normally located quite far from the villages, it is costly and physically demanding for farmers to collect the manure produced and it is not usually free.

6 The deep maize processing sector uses maize to produce sugar, alcohol, glutamic acid, lysine, citric acid and other products.

7 Temperature is one of the most important factors affecting biogas production. Although simple biogas digesters are buried in the ground, low temperatures restrict biogas production. Thus, rural households in China's subtropical areas such as the northeastern region are suitable for the adoption of biogas digester technologies.

8 There are data discrepancies between different sources on the annual bioethanol production figures.

$910 \%$ percent ethanol blended into fuel.

10 China Economic Times 2014. 'China's Bioethanol development in a conundrum: policy shift and companies flees' at http://www.cet.com.cn/nypd/xny/1092980.shtml. Accessed 14 April 2014.

11 China has a consumption tax on gasoline, naphtha, solvent oil and lubricating oil, and value-added tax is charged to enterprises or individuals who sell merchandise, provide processing, repair or assembling services, or import goods within China. See http:/ / www.china.org.cn/english/LivinginChina/202770.htm.

12 People.com. 2011. 'COFCO bioenergy Ltd received VAT refund 38.78 million RMB' at http://finance.people.com.cn/GB/70846/16299074.html. Accessed 13 April 2014.

13 People.com. 2007. 'Future Development of Bioethanol will be noncereal based and corn based bioethanol plants will be halted' and http://finance.people.com.cn/ GB/5844810.html. Accessed 14 April 2014.

14 In the case of biogas, there are a large number of private companies and research institutes engaged in producing biogas digesters, research and technology, and engineering projects. In large centralized biogas projects, they do play an important role, but in the development of the vast rural household based biogas projects, their role is marginal at best.

15 For instance, according to the large-scale survey done by Wei Qu et al (2013), the government's biogas policy, especially the promotion policy, has had a significant 
impact on the likelihood of farmers to build a biogas digester.

16 Refer to International Business Times at http:/ / www.ibtimes.com/china-worlds-largest-net-importer-crude-oil-eia-1563247. Accessed on 21 April 2014.

17 Financial Times (3 March 2014) 'Time China got serious on pollution' at http:/ /www. ft.com/cms/s/0/b2becca0-a2df-11e3-ba21-00144feab7de.html\#axzz3JxuV8b4i. Accessed 17 March 2014.

18 See Chinanews at http:/ / www.chinanews.com/sh/2013/03-07/4624407.shtml. Accessed 17 April 2014.

19 See Xinhuanet at http://news.xinhuanet.com/fortune/2013-05/25/c_124763505. htm. Accessed 17 April 2014.

20 See People.com at http://politics.people.com.cn/GB/70731/17968454.html. Accessed 18 April 2014.

21 According to the Ministry of Agriculture, a 'family farm' would engage most members of a single family in agricultural production, allowing them to make farming their main source of income. 'Family' or 'specialized' farms centralize distinct plots of land to form a large-scale operation. Family farming is similar to a fixed profession, such as that seen in Western countries, according to Guan Ruijie, a supervisor from the Ministry. See http://www.newschinamag.com/magazine/china-promotes-family-farms. Accessed 15 April 2014.

22 See people.com.cn at http://politics.people.com.cn/n/2014/0224/c1001-24440981. html. Accessed 12 April 2014.

23 See South China Morning Post at http://www.scmp.com/business/economy/article/1133255/china-must-invest-abroad-food-security-forum-told. Accessed 15 April 2014; Loro Horta 'The rice paddy beyond the sea.' PacNet. Number 64.5 August 2014.

24 See Terazono, E. Financial Times (11 September 2013) 'China sees rising appetite for corn imports. http://www.ft.com/cms/s/0/4d738f8e-19f5-11e3-93e8-00144feab7de. html\#axzz3XqHPBLIG. Accessed 15 April 2014.

\section{REFERENCES}

Chang, Shiyan, Zhao Lili, Govinda R. Timilsina and Zhang Xiliang 2012. Development of Biofuels in China: Technologies, Economics and Policies. Policy Research Working Paper: the World Bank.

Cheng, Xiaodun, Zhu Fuyun and Huang Tianzhu 2013. 'Analysis of the characteristics of China's Corn market: based on the development of bioethanol'. Economic Theory and Practice. 9 (371): 88-89.

China Bureau of Statistics 2013. China Statistical Yearbook 2013. China Statistics Press: Beijing.

Dong, Fengxia 2007. Food Security and Biofuel Development: The case of China. Briefing paper, Iowa State University.

Lu, Hongyan, Yan Jiong, Xue Bing and Peter Heck 2013. 'Cooperation Challenges of Developing Centralized Biogas Plants in China'. International Journal of Energy Science. 3 (2): 60-69.

Ministry of Agriculture 2013. China Rural Energy Yearbook 2009-2013. Beijing: China Agricultural Press.

Ministry of Agriculture. 2008. China Rural Energy Yearbook 2000-2008. Beijing: China Agricultural Press.

OECD-FAO. 2013. OECD-FAO Agricultural Outlook 2013-2022. OECD Publications.

Qiu, Huanguang, Huang Jikun, Michiel Keyzer, Wim van Veen, Scott Rozelle, Gunether 
Fishing and Tatiana Ermolieva 2009. Biofuel Development, Food Security and the Use of Marginal Land in China. Paper presented at 17th Annual Conference of the European Association of Environmental and Resource Economists in Amsterdam June 2009.

Qiu, Huanguang, Sun Laixiang, Huang Jikun and Scott Rozelle 2012. 'Liquid Biofuels in China: Current Status, government policy and future opportunities and challenges'. Renewable and Sustainable Energy Review. 16: 3095-3104.

Rabobank 2012. Industrialization of China's Pork Supply Chain. Rabobank Industry Note. Renewable Energy Policy Network for the 21st Century 2013. Renewables 2013: Global Status Report. Industry Report: 27-31.

Scott, Ryan and Jiang Junyang 2012. China Biofuel Annual Report. USDA Report.

Scott, Ryan and Jiang Junyang 2013. China Biofuel Annual Report. USDA Report.

Wang, Fei, Cai Yaqing and Chou Huanguang 2012. 'Current Status, Incentives and Constraints for future development of biogas in China'. Agricultural Engineering Journal. 28 (1): 184-189.

Wei, Qu, Qin Tu and Bettina Bluemling 2013. 'Which factors are effective for farmers' biogas use?-Evidence from a large scale survey in China'. Energy Policy. 63:26-33.

Wood Mackenzie 2012. 'China: Study Says Shale Gas Will Not Satisfy Demand' Pipeline E Gas Journal. Vol. 239 (8): 74-77.

Xia, Zuzhang 2013. Domestic biogas in a changing China: can biogas still meet the energy needs of China's rural households. International Institute for Environmental and Development, London.

Xue, Xiaofei 2013. 'Survey report of the current status of rural biogas'. Science ETechnology Information. 27: 116-117.

Yang, Hailong, Lv Yao, Wang Lou and Shen Lei 2012. 'The ecology risk of large scale planation of energy crops in China'. Journal of Anhui Agricultural Science. 40 (28): 13941-14151.

Yu, Chen, Gaihe Yang, Sandra Sweeney and Yongzhong Feng 2010. 'Household biogas use in China: A study of opportunities and constraints'. Renewable and Sustainable Energy Review. 14: 545-549.

Zhang, Ming and Lai Ming 2007. 'Development of Rural Biogas: Problems and Solutions'. Journal of Anhui Agricultural Science. 35 (7): 2108-2110. 